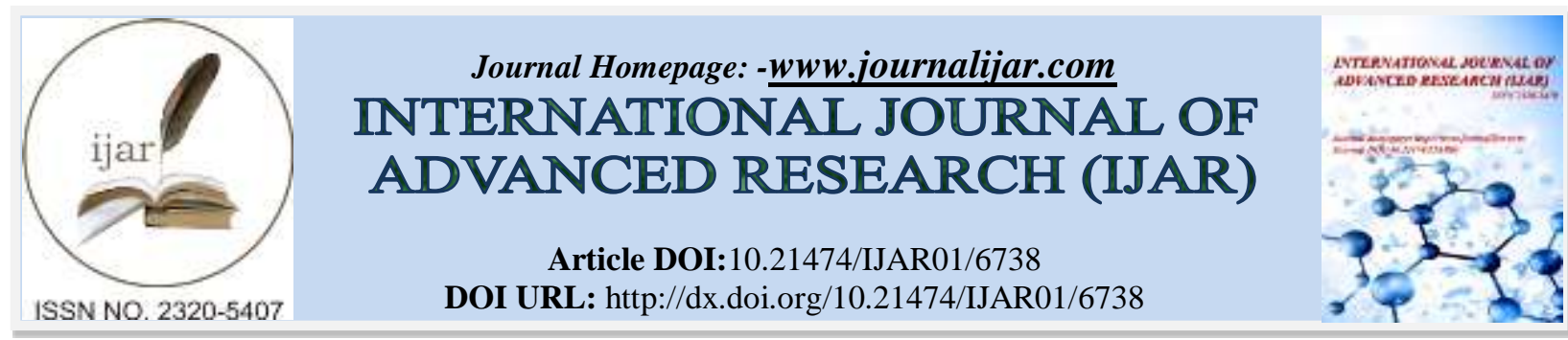

RESEARCH ARTICLE

\title{
PHENOTYPIC AND GENOTYPIC CHARACTERIZATION OF LISTERIA SPECIES ISOLATED FROM CHICKEN AND MILK PRODUCTS.
}

Wafaa. M.M Hassan, Ashraf. A. Abd El Tawwab Fatma, I. El- Hofy and Haidy. T. Zaki. Animal Health Research Institute, Bacteriology, Immunology and Mycology Dep. Fac.Vet.Med.Benha Univ.

\section{Manuscript Info}

Manuscript History

Received: 13 January 2018

Final Accepted: 15 February 2018

Published: March 2018

Keywords:-

L.monocytogenes, poultry, milk , resistance .

\section{Abstract}

L.monocytogenes is wide spread in the environment and can be isolated from a wide variety of food. As such it can be expected to be present in ready-to-eat foods that contain raw ingredients. The risk caused by $L$. monocytogenes is dependent on the food and how long it is stored. To estimate the incidence and levels of Listeria spp. in different food sources, A total of 200 random samples which collected from different sources 65 samples isolated from poultry, 45 from poultry byproducts (Frozen chicken meat balls (kofta), Frozen chicken burger and frozen chicken sausages), 20 from pasteurized milk ,30 from milk products (Feta cheese ,cream cheese )and 40 from poultry eggs .Only 7(14\%) of samples that collected from suspected isolates and detected on Oxford agar, PALCAM agar and ALOA agar were suspected to be Listeria spp. The in-vitro antimicrobial sensitivity test showed that the isolated L.monocytogenes were sensitive to Sulphamethoxazole/trimethoprim, Gentamycin ,Ceftazidime and Cephazoline followed by Sulphamethoxazole, ceftriaxone, weak sensitivity to Penicillin, While they were resistant to Erythromycin, Clindamycin, Ampicillin. All L.monocytogenes were virulent strains as all of them were positive to CAMP test; showed narrow zone of $\beta$-hemolysis on sheep blood agar .The PCR results for Listeria isolates showed that all strains are L.monocytogenes and detect 16SrRNA gene and have mefA ,tet $M$ and ampC genes (100\%) as resistance genes while Cat and Aad6 genes detected as $85.7 \%$ and $71.4 \%$ respectively.

Copy Right, IJAR, 2018,. All rights reserved.

\section{Introduction:-}

Listeria monocytogenes is one of the sub-species from the genus Listeria. L. monocytogenes is a global concern and can be transmitted by direct contact and digestion and cause a serious diseases: meningitis, abortion, Spontaneous Bacterial Peritonitis (SBP), listeriosis and even death (How et al., 2015).Listeria monocytogenes is a Gram-positive rod-shaped non-capsulated bacterium that form single short chains (Theivagt et al., 2006), facultative anaerobic, nonspore-forming, rod-shaped bacteria $0.5 \mathrm{~mm}$ in width and 1-1.5 $\mathrm{mm}$ in length (Vera et al., 2013).

The organism can survive at varying temperatures ranging from 4 to 37C (Janakiraman, 2008). The bacterium can tolerate a wide range of $\mathrm{pH}$ and temperatures. Optimum growth occurs at 30-37C but the organism can multiply at4- 
45C. A typical tumbling motility is observed around25C. It can grow at $\mathrm{pH} 4.5-9.6$, although the growth is minimal at low $\mathrm{pH}$ and low temperatures (OIE, 2014).

The centralized production of prepared ready-to-eat food products increases the risk of higher levels of contamination, since it requires that foods be stored for long periods at refrigerated temperatures that favor the growth of Listeria. During the preparation, transportation and storage of prepared foods, the organism can multiply to reach a threshold needed to cause infection (Bortolussi, 2008). Egg and egg products have never been caused listeriosis but is most frequently isolated from egg shells and in the environment of laying hens.(Chemaly et al., 2008) L. monocytogenes can Survive 90 days on stored egg at 5C and for 15 days at 10C (Gandhi and chikindas, 2007 ).

Invasiveness by virulence factors, L.monocytogenes expresses cell-surface and secreted proteins that enable attachment to host cells, escape from the phagocytic vacuole by Internalin A (inIA) and Internalin B (inIB) mediate the attachment of $L$. monocytogenes to the surface of host cells. Once ingested the bacterium produces listeriolysin (LLO) to escape from the phagosome and lyses the phagosomal membrane,The bacterium then multiply rapidly in the cytoplasm and moves through the cytoplasm to invade adjacent cells by polymerizing actin to form long tails ,the actin-assembly-inducing protein (ActA) which propels bacteria through the cell and into neighbouring cells, (Todar ,2008). L. monocytogenes lacking a functional ActA is severely dampened in its pathogenicity. This reduction might not only be due to a lack in intracellular motility however, ActA involved in aggregation and biofilm formation, possibly affecting intestinal adherence.(Travier et al., 2013 ).

Each step requires expression of specific virulence factors. The major virulence genes are clustered together on the chromosomes and regulated by the positive regulatory factor A protein PrfA (Positive Regulatory Factor A (PrfA). (Scortti et al.,2007 and Freitag et al.,2009).

The present study was conducted to estimate the prevalence of listeria species in poultry and milk products with special interest to L.monocytogenes. In addition to carry out the antibiotics sensitivity testing of them and detection of some resistance factors of L.monocytogenes by PCR technique.

\section{Material And Methods:-}

\section{Samples collection:-}

Two hundred random samples which collected from different sources 65samples isolated from poultry , 45 from poultry byproducts (Frozen chicken meat balls (kofta),Frozen chicken burger and frozen chicken sausages), 20 from pasteurized milk 30 from milk products (Feta cheese, cream cheese) and 40 from poultry eggs. The samples were collected in sterile plastic bags, kept in ice box and transferred with a minimum delay to the laboratory for studying the presence of listeria species.

\section{Bacteriological examination:-}

A-Primary stage: One $\mathrm{ml}$ of sample was inocluted into $9 \mathrm{ml}$ fraser broth 1, half fraser broth (without supplement) and incubated aerobically at $30 \pm 1 \mathrm{c}$ for $24 \pm 3$ hours .B-Secondary stage : one $\mathrm{ml}$ of incubated broth was inoculated into $9 \mathrm{ml}$ fraser broth 2 , full strength fraser broth (with supplement) and incubated at $37 \mathrm{C}$ for $48 \pm 3$ hours .C-Third stage $: 0.1 \mathrm{ml}$ of incubated fraser broth was streaked onto the following media : ALOA agar; PALCAM agar and Oxford agar plates then the plates were incubated at $37 \pm 1$ Cfor 48 hours and examined after $24 \pm 3$ hours. The listeria like colonies were picked and streaked onto Tryptic Soy agar ( Bio-life ) with $0.6 \%$ yeast extract (TSA,YA) then, incubated at $35 \mathrm{C}$ for 48 hours. The isolates were morphologically identified by Gram stain and biochemical tests according to (Markey et al.,2013)

\section{In -Vitro anti-microbial sensitivity tests:-}

The isolated L.monocytogenes strains were subjected to the sensitivity test against different antibiotics, using the disc and agar diffusion method: antibiotic discs are Erythromycin(E), Penicillin (P), Sulphamethoxazole (SM), ceftriaxone (CRO), Gentamycin (CN), Clindamycin (DA), Ampicillin (AM), Cefazoline (KZ), Sulphamethoxazole/ trimethoprime (SXT), ceftazidime (CAZ). (Finegold and Martin, 1982 and NCClS, 1999)

\section{Virulence tests:-}

Hemolytic activity: all isolates were cultured on 5\% sheep blood agar to determine their hemolytic activity . Also, they were subjected to CAMP test (Mckellar,1994) by streaking staphylococcus aureus strains in single straight 
lines in parallel on sheep blood agar plates, the isolated listeria strains streaks perpendicularly,(1-2mm).then incubated for $24-48$ hours at $35 \mathrm{C}$,enhanced zone of $\beta$-hemolysis considered as a positive reaction.

\section{Genotypic detection of isolated L.monocytogenes and some resistance genes in them using polymerase chain} reaction (PCR):-

PCR using six sets of primers was used for genotypic detection of L.monocytogenes strains by 16SRNA and five resistance genes as macrolides (mefA); tetracycline (tetM); $\beta$-lactams (ampC) ; chloramphenicol(cat) and aminoglycosides (Aad6).

It was applied on seven isolated L.monocytogenes following QIAamp® DNA Mini Kit instructions (Catalogue no. 51304),Emerald Amp GT PCR master mix (Takara) Code No. RR310A and Agarose 1\% (Sambrook et al., 1989).The PCR condition can amplify specific products as shown in Table (2). Temperature and time condition of the primers during PCR are shown in table (3) according to specific authors and Emerald Amp GT PCR master mix (Takara) kit.

\section{Results:-}

Of the total 200 different samples analyzed, L. monocytogenes was detected in 7 samples with prevalence of 14\%; represented as in poultry, poultry byproducts, pasteurized milk, milk byproducts and poultry eggs, listeria percentage were $0 / 65(0 \%), 4 / 45(8.9), 0 / 20(0 \%), 0 / 30(0 \%), 3 / 40(7.5 \%)$ isolates, respectively as Table (1) The isolated colonies grow well on ALOA agar producing blue-green colonies surrounded by opaque halo and on PALCAM agar gives grey-green with black center and black halo against cherry-red background and on Oxford agar gives grayish colonies surrounded by black halos. They were Gram - positive bacilli or coccobacilli ;motile showing Umbrella -shaped motility. On biochemical reactions ,they produce acid from L-rhamnose, dextrose and but not with and mannitol. The results of virulence tests showed that, all isolated L.monocytogenes strains showed narrow zone of $\beta$-hemolysis on 5\% sheep blood agar, positive in CAMP test and showed as arrow-shaped zone of weak enhanced hemolysis at junction of tested strains and S.aureus strain.

The result of in -vitro sensitivity test phenotypically showed that ,the isolated L.monocytogenes were sensitive to Sulphamethoxazole / trimethoprim (100\%), followed by Gentamycin, Ceftazidime and Cephazoline (71.4\%), followed by Sulphamethoxazole, ceftriaxone (42.8\%), weak sensitivity to Penicillin (14.2\%). While the isolated were resistant to Erythromycin, Ampicillin and Clindamycin as Fig (1). Agarose gel electrophoresis results of the isolated samples by PCR detected that all the seven isolates were L.monocytogenes duo to detection of 16SrRNA gene and genotypic detection of antibiotic resistance showed that all isolates were $100 \%$ resistant to $\beta$-lactams ,tetracycline and macrolides detected by Ampc, tetM and mefA genes respectively, while $85.7 \%$ of isolates were resistant to chloramphenicol detected by Cat gene and $71.4 \%$ of isolates were resistant to aminoglycosides detected by Aad6 gene.

Table 1:-Total number and percentage of positive samples for listeria isolation from examined samples.

\begin{tabular}{|c|c|c|c|c|c|}
\hline & & & \multicolumn{3}{|c|}{ Positive percentage } \\
\hline Samples & $\begin{array}{c}\text { Number of } \\
\text { samples }\end{array}$ & $\begin{array}{c}\text { Number of } \\
\text { positive } \\
\text { samples }\end{array}$ & $\% 1$ & $\% 2$ & $\% 3$ \\
\hline Poultry & 65 & zero & zero & zero & zero \\
\hline Frozen wings & 35 & zero & zero & zero & zero \\
\hline Frozen breast & 30 & zero & zero & zero & zero \\
\hline Poultry products & 45 & 4 & 8.9 & 57.1 & 2.0 \\
\hline $\begin{array}{l}\text { Frozen chicken meat balls } \\
\text { (kofta) }\end{array}$ & 10 & 2 & 4.4 & 28.5 & 1.0 \\
\hline Frozen chicken burger & 15 & 1 & 2.2 & 14.2 & 0.5 \\
\hline frozen chicken sausages & 20 & 1 & 2.2 & 14.2 & 0.5 \\
\hline Pasteurized Milk & 20 & zero & zero & zero & zero \\
\hline Milk products & 30 & zero & zero & zero & zero \\
\hline Feta cheese & 10 & zero & zero & zero & zero \\
\hline Cream cheese & 20 & zero & zero & zero & zero \\
\hline Poultry eggs & 40 & 3 & 7.5 & 42.8 & 2.5 \\
\hline Total & 200 & 7 & 3.5 & 100.0 & 3.5 \\
\hline
\end{tabular}


1. Percentage in relation to total number of samples in each raw.

2. Percentage in relation to total number of positive samples (7).

3. Percentage in relation to total number of collected samples 200).

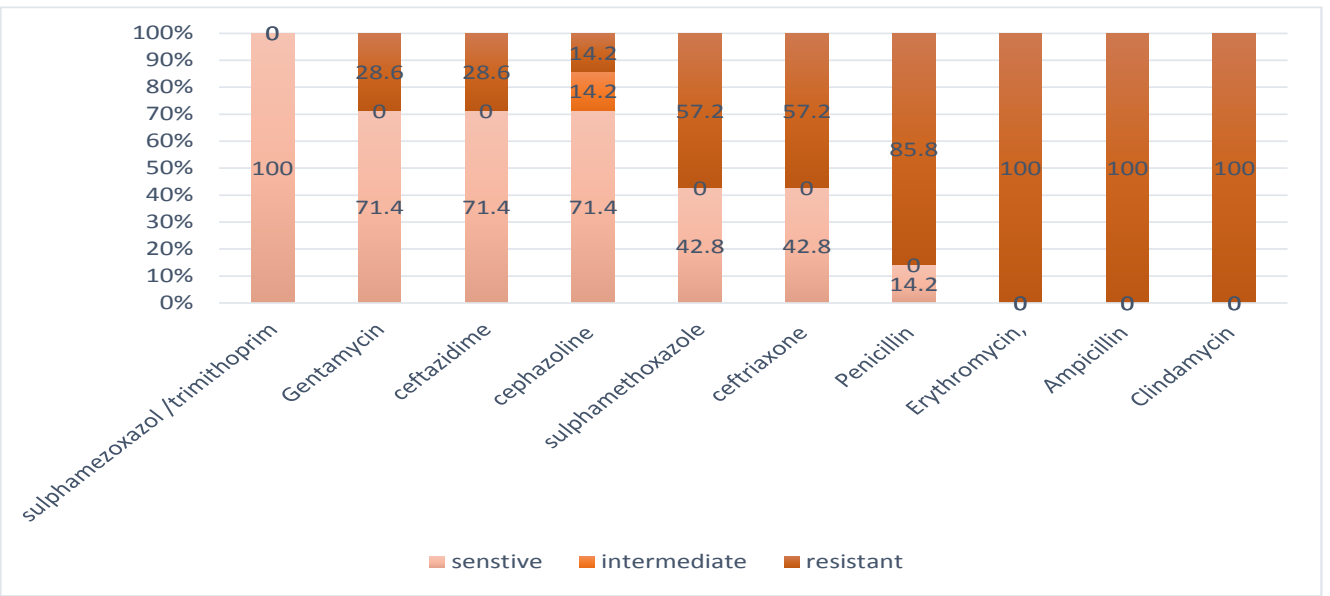

Fig.1:- In-vitro antimicrobial sensitivity test for isolated L.monocytogenes .

Table 2:- Oligonucleotide primers sequences sources

\begin{tabular}{|c|c|c|c|}
\hline Primer & Sequence & $\begin{array}{c}\text { Amplified } \\
\text { product }\end{array}$ & Reference \\
\hline \multirow[t]{2}{*}{$16 S r R N A$} & ggA CCg ggg CTA ATA CCg AAT gAT AA & \multirow[t]{2}{*}{$1200 \mathrm{bp}$} & \multirow{2}{*}{$\begin{array}{c}\text { Kumar et al., } \\
2015\end{array}$} \\
\hline & TTC ATg TAg gCg AgT TgC AgC CTA & & \\
\hline \multirow[t]{2}{*}{ Aad6 } & AGAAGATGTAATAATATAG & \multirow[t]{2}{*}{$978 \mathrm{bp}$} & \multirow{8}{*}{$\begin{array}{c}\text { Morvan et al., } \\
2010\end{array}$} \\
\hline & CTGTAATCACTGTTCCCGCCT & & \\
\hline \multirow[t]{2}{*}{ Cat } & GAACAGGAATTAATAGTGAG & \multirow[t]{2}{*}{$384 \mathrm{bp}$} & \\
\hline & GGTAACCATCACATAC & & \\
\hline \multirow[t]{2}{*}{ mefA } & AGTATCATTAATCACTAGTGC & \multirow[t]{2}{*}{$345 \mathrm{bp}$} & \\
\hline & TTCTTCTGGTACTAAAAGTGG & & \\
\hline \multirow[t]{2}{*}{ tetM } & GTGGACAAAGGTACAACGAG & \multirow[t]{2}{*}{$405 \mathrm{bp}$} & \\
\hline & CGGTAAAGTTCGTCACACAC & & \\
\hline \multirow[t]{2}{*}{ ampC } & TTCTATCAAMACTGGCARCC & \multirow[t]{2}{*}{$550 \mathrm{bp}$} & \multirow{2}{*}{$\begin{array}{l}\text { SRINIVASAN } \\
\text { et al. } 2005\end{array}$} \\
\hline & CCYTTTTATGTACCCAYGA & & \\
\hline
\end{tabular}

Table 3:- cycling conditions of the different primers during cPCR

\begin{tabular}{|c|c|c|c|c|c|c|}
\hline Gene & $\begin{array}{c}\text { Primary } \\
\text { denaturation }\end{array}$ & $\begin{array}{c}\text { Secondary } \\
\text { denaturation }\end{array}$ & Annealing & Extension & $\begin{array}{c}\text { No. of } \\
\text { cycles }\end{array}$ & $\begin{array}{c}\text { Final } \\
\text { extension }\end{array}$ \\
\hline $16 \mathrm{~S}$ & $94^{\circ} \mathrm{C}$ & $94^{\circ} \mathrm{C}$ & $60^{\circ} \mathrm{C}$ & $72^{\circ} \mathrm{C}$ & 35 & $72^{\circ} \mathrm{C}$ \\
$r R N A$ & $5 \mathrm{~min}$. & $30 \mathrm{sec}$. & $1 \mathrm{~min}$. & $1 \mathrm{~min}$. & & 12 min. \\
\hline Aad6 & $94^{\circ} \mathrm{C}$ & $94^{\circ} \mathrm{C}$ & $55^{\circ} \mathrm{C}$ & $72^{\circ} \mathrm{C}$ & 35 & $72^{\circ} \mathrm{C}$ \\
& $5 \mathrm{~min}$. & $30 \mathrm{sec}$. & $40 \mathrm{sec}$. & $50 \mathrm{sec}$. & & 10 min. \\
\hline Cat & $94^{\circ} \mathrm{C}$ & $94^{\circ} \mathrm{C}$ & $55^{\circ} \mathrm{C}$ & $72^{\circ} \mathrm{C}$ & 35 & $72^{\circ} \mathrm{C}$ \\
& $5 \mathrm{~min}$. & $30 \mathrm{sec}$. & $40 \mathrm{sec}$. & $40 \mathrm{sec}$. & & 10 min. \\
\hline mefA & $94^{\circ} \mathrm{C}$ & $94^{\circ} \mathrm{C}$ & $55^{\circ} \mathrm{C}$ & $72^{\circ} \mathrm{C}$ & 35 & $72^{\circ} \mathrm{C}$ \\
& $5 \mathrm{~min}$. & $30 \mathrm{sec}$. & $40 \mathrm{sec}$. & $40 \mathrm{sec}$. & & 10 min. \\
\hline$t e t M$ & $94^{\circ} \mathrm{C}$ & $94^{\circ} \mathrm{C}$ & $55^{\circ} \mathrm{C}$ & $72^{\circ} \mathrm{C}$ & 35 & $72^{\circ} \mathrm{C}$ \\
& $5 \mathrm{~min}$. & $30 \mathrm{sec}$. & $40 \mathrm{sec}$. & $40 \mathrm{sec}$. & & 10 min. \\
\hline ampC & $94^{\circ} \mathrm{C}$ & $94^{\circ} \mathrm{C}$ & $50^{\circ} \mathrm{C}$ & $72^{\circ} \mathrm{C}$ & 35 & $72^{\circ} \mathrm{C}$ \\
& $5 \mathrm{~min}$. & $30 \mathrm{sec}$. & $40 \mathrm{sec}$. & $45 \mathrm{sec}$. & & 10 min. \\
\hline
\end{tabular}




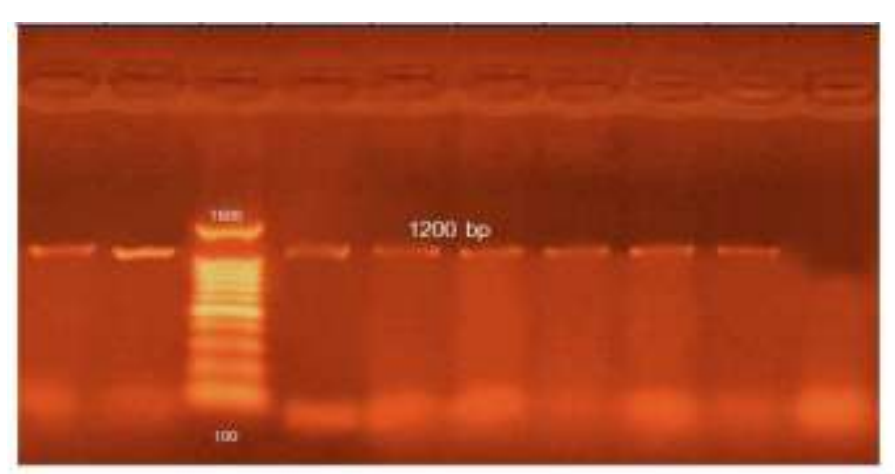

Fig. 2:- 16SrRNA genes . Lane L:IUU-1JUUbp Ladder. Neg:INegative control . Yos. :postive control at (1200bp). Lanes 1 to 7 :L.monocytogenes (16SrRNA) gene positive.

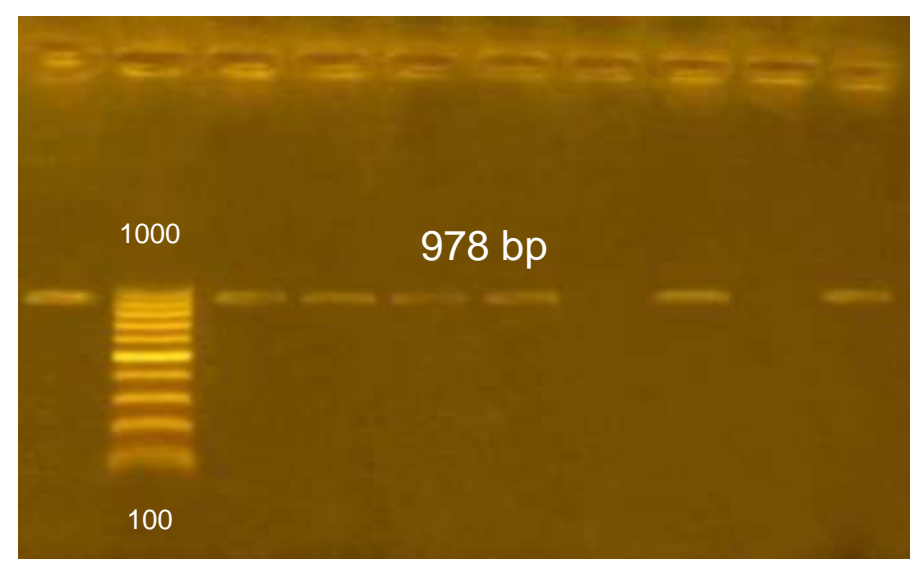

Fig.3:- Aad6 gene. Lane L:100-1000bp Ladder. Neg:Negative control . Pos:Positive control at (978bp ). Lanes 1 to 7 :L.monocytogenes (Aad6 )gene positive except two samples.

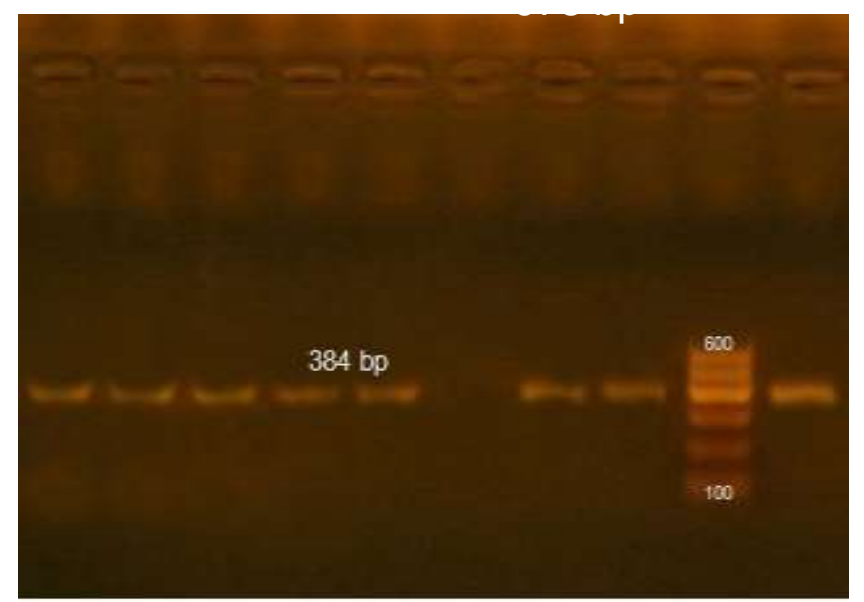

Fig.4:- Cat gene. Lane L:100-600bp Ladder. Neg: Negative control . Pos:Positive control at (384bp ). Lanes 1 to 7 :L.monocytogenes (Cat gene) positive in all samples except one sample. 


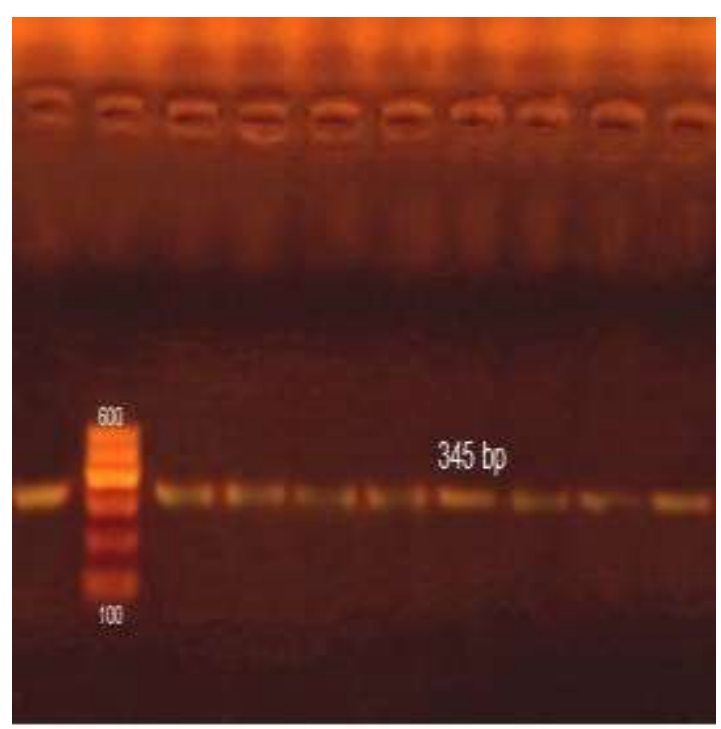

Fig. 5:- MefAgene. Lane L:100-600bp Ladder. Neg: Negative control . Pos:Positive control at (345bp ). Lanes 1 to7 L.monocytogenes (MefAgene) positive .

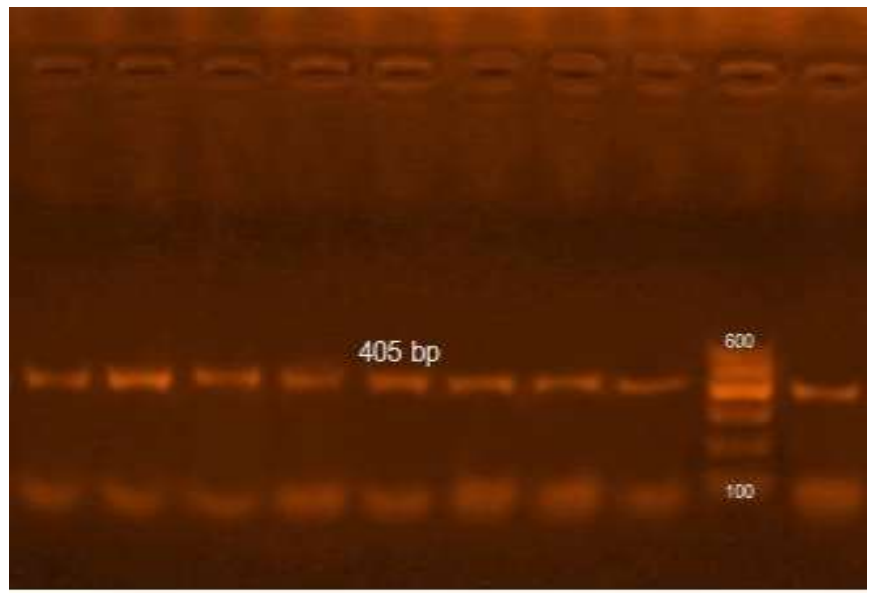

Fig.6:-tet M gene. Lane L:100-600bp Ladder. Neg: Negative control . Pos:Positive control at (405bp ). Lanes 1 to 7 :L.monocytogenes (tet $\mathrm{M}$ gene) positive . 


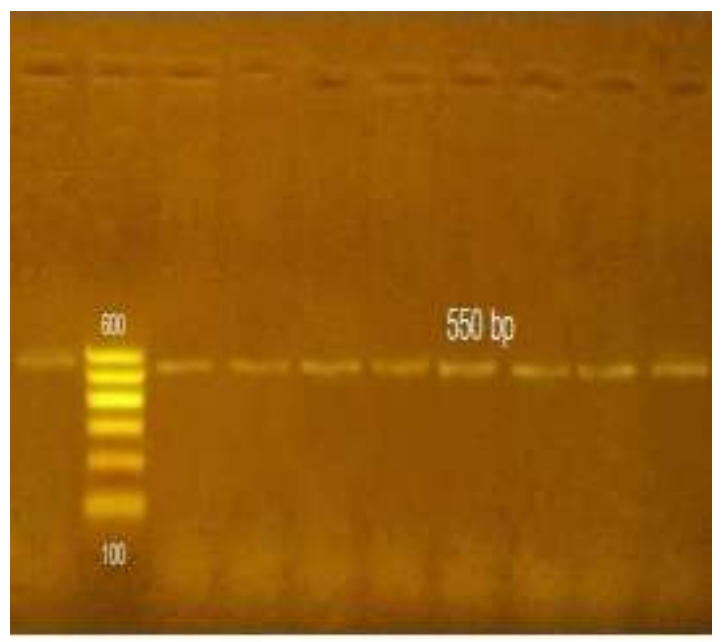

Fig.7:- AmpCgene. Lane L:100-600bp Ladder. Neg: Negative control . Pos:Positive control at (550bp ). Lanes 1 to 7 :L.monocytogenes (AmpCgene) positive

\section{Discussion:-}

Listeriosis is of great public health concern because of its high mortality (20 to 30\%) and its common source epidemic potential. The most important aspect in food hygiene is the ability of the bacteria to survive in a wide range of temperatures and to make biofilms on various environmental surfaces, which serve as natural habitats or reservoirs (Duggan and Phillips, 1998).

Ability of L. monocytogenes to cause disease depends upon the expression of virulence factors and immune status of individuals. Usually individuals having weakened cell-mediated immunity are more susceptible to $L$. monocytogenes. (Lecuit et al., 2004)

In this research we found that L. monocytogenes was detected in 7 samples out of 200 (14\%)represented as in poultry, poultry byproducts, pasteurized milk, milk byproducts and poultry eggs,with percentages $0 / 65(0 \%)$, $4 / 45(8.9 \%), 0 / 20(0 \%), 0 / 30(0 \%), 3 / 40(7.5 \%)$ respectively that disagreed with that recorded by (Zeinali et al., 2017)

Listeria monocytogenes wasn't found in Frozen wings of poultry, frozen breast of poultry that totally disagreed with (Reiter et al., 2005)

The result of in vitro sensitivity test showed that ,the isolated L.monocytogenes were highly sensitive to Sulphamethoxazole /trimethoprim (100\%), so we can use it in its medication (Swaminathan and Gerner- Smidt, 2007), followed by Gentamycin Ceftazidime and Cephazoline (71.4\%), followed by Sulphamethoxazole, ceftriaxone (42.8\%), weak sensitivity to Penicillin (14.2\%), while the isolated strains were resistant to Erythromycin, Ampicillin and Clindamycin and these results came in accordance with those recorded by (Zeinali et al., 2017) and disagreed with (Altuntas et al.,2012). All L.monocytogenes isolates were positive to CAMP test and showed narrow zone of $\beta$ heamolysis in sheep agar, the similar results were reported by (Marrouf et al ., 2007). Regarding to the occurance of 16SrRNA genes in L.monocytogenes isolates, the obtained result revealed that, it was amplified in all seven tested isolates ,that agreed with those recorded by (Ciolacu et al .,2015)

Chloramphenicol encoded by (Cat )gene was amplified in six tested isolates as in Fig.(4),that similar recorded by (Poyart-Salmeron et al.,1990). macrolides encoded by (mefA) gene was amplified in all seven tested isolates Fig(5) that resemble the result of our phenotypic antibiotic sensitivity test Fig(1), and disagreed with (Leclercq,2002).Tetracycline encoded by (tetM) gene was detected in all L.monocytogenes isolates that came in accordance with (Granier et al.,2011), 71.4\% of the L. monocytogenes isolates were resistant to aminoglycosides that encoded by (Aad6) gene that the same reported by (Charpentier et al., 1995) while 100\% of the $L$. monocytogenes isolates were resistant to $\beta$-lactam that encoded by (Ampc) gene that resemble our result of phenotypic antibiotic sensitivity test ampicillin and penicillin resistance and also similar to recorded by (Njagi et al., 2004) 
At the last, we can conclude from the present work that L.monocytogenes are mainly food born pathogen that could contaminate poultry and milk products causing listeriosis. Sulphamethoxazole / trimethoprim is antibiotic of choice for listerial infection treatment followed by Gentamycin, Ceftazidime and Cephazoline L.monocytogenes express multidrug resistance to several antibiotics as Chloromphenicol, tetracycline ,Erythromycin, Ampicillin ,Penicillin and Clindamycin .All the isolated L.monocytogenes were CAMP Positive and produce $\beta$-zone of heamolysis .In PCR assured that the seven strains are listeria monocytogenes by detection of 16SrRNA gene and genotypic detection of resistance genes (Cat,MefA,Ampc,Aad6 and tet M).

\section{References:-}

1. Altuntas EG, Kocan D, Cosansu E, Ayhan K, JunejaVK, Materon2012 L.monocytogenes Antibiotic and bacteriocin sensitivity of Listeria monocytogenes strains isolated from different foods. JFNS. 2012 Mar;3(3):363-8. DOI: 10.4236/fns.2012.33052

2. Bortolussi, M.D. (2008). Listeriosis: a primer CMAJ. 2008 October 7; 179(8): 795-797.

3. Charpentier E, Gerbaud G, Jacquet C, Rocourt J, and Courvalin P. Incidence of antibiotic resistance in Listeria spp. J Infect Dis 1995;172:277-281

4. Chemaly ,M.,M.T. Toquin, Y. Le Notre and P. Fravalo,2008. Prevalence of Listeria monocytogenes in poultry production in France. J.Foot ., 71:1996-2000.

5. Ciolacu, L.,nicolau, A.I., Wagner, m., Rychli ,K., 2015 .Listeria monocytogenes isolated from food samples from a Romanian Black market show distinct virulence profiles . Int . J. Food Microbial., 209:44-51

6. Duggan., J., Phillips., C.A. (1998). Listeria in the domestic environment. Nutrition \& Food Science. 98, 73-79.

7. Finegold, S.M., Martin, W.J.1982.Bailley and Scott Diagnostic Microbiology $6^{\text {th }}$ ed., C.V. Mosby Co. St. Louis. Toronto, London.

8. Freitag NE, Port GC, Miner MD:Listeria monocytogenes-from saprophyte to intracellular pathogen. Nat Rev Microbiol 2009, 7:623-628.

9. Gandhi, M. and M.L.Chikindas,2007.Listeria :A foodborne pathogen that knows how to survive Int.J.Food Microbial., 113:1-15.

10. How J, Azar MM, Meyer JP. (2015): Are Nectarines to Blame? A Case Report and Literature Review of Spontaneous Bacterial Peritonitis Due to Listeria monocytogenes. Conn Med. 2015 Jan;79(1):31-36. PubMed PMID: 25960571; PubMed Central PMCID: PMC4423821

11. Kumar, A.; Grover, S. and Batish, V.K. (2015): Exploring specific primers targeted against different genes for a multiplex PCR for detection of Listeria monocytogenes. 3 Biotech (2015) 5:261-269.

12. Lecuit, M., Nelson, D.M., Smith, S.D., Khun, H., Huerre, M., Vacher-Lavenu, M.C., Gordon, J.I., Cossart, P. (2004). Targeting and crossing of the human maternofetal barrier by Listeria monocytogenes: role of internalin interaction with trophoblast E-cadherin. ProcNatlAcadSci U S A 101, 6152-6157.

13. Leclercq, R.2002.Mechanismsofresistancetomacrolidesandlincosamides: nature of the resistance elements and their clinical implications. Clin. Infect. Dis. 34:482-492.

14. Marrouf, A.A., El-Bealawy, M.A., Moubarak, M.G. 2007 . Some studies of listeriosis in sheep atEl-Kaliobia government.J.Egypt.Vet.Med.Assoc.67(4):27-40.

15. McKellar,R.C.1994.Use of the CAMP test for identification of Listeria monocytogenes .Appl.Environ. Microbial.,60 (12):4219-4225.

16. Morvan, A.; Moubareck, C.; Leclercq, A.; Hervé-Bazin, M.; Bremont, S.; Lecuit, M.; Courvalin, P. and Le Monnier, A. (2007): Antimicrobial Resistance of Listeria monocytogenes Strains Isolated from Humans in France. ANTIMICROBIAL AGENTS AND CHEMOTHERAPY, p. 2728-2731 Vol. 54, No. 6.

17. NCCLS.1999 .National Committee For Clinical Laboratory Standards. Performance Standards for Antimicrobial Disk and Dilution Susceptibility Tests for Bacteria isolated from animals .Approved Standard M31-A. NCCLS, Wayne,USA.

18. Njagi LW, Mbuthia PG, Bebora LC, Nyaga PN, Minga U, OlsenJE. Carrier status for Listeria monocytogenes and other Listeriaspecies in free range farm and market healthy indigenous chickens and ducks. East African Med J 2004;81:529-533

19. OIE. 2014. Listeria monocytogenes. Chapter 2.9.7. Manual ofdiagnostic tests and vaccines for terrestrial animals. p.1-18. Available from: http://www.oie.int/manual-of - diagontic- tests-and- vaccines for terrestrial animals

20. Poyart-Salmeron, C., C. Carlier, P. Trieu-Cuot, A. L. Courtieu, and P. Courvalin. 1990. Transferable plasmidmediated antibiotic resistance in Listeria monocytogenes. Lancet 335:1422-1426

21. Reiter,M.G.R; Camila B.M.M.; Carmen, L. and Jordano,R. (2005): Occurrence of Campylobacter and L.monocytogenes in a poultry Processing plant. J. food Prot.,68(9):1903-1906. 
22. Sambrook, J.; Fritscgh, E.F.;andMentiates (1989): Molecular coloning. A laboratory manual. Vol !., Cold spring Harbor Laboratotry press, New York.

23. Scortti M, Monzo HJ, Lacharme-Lora L, Lewis DA, Vazquez- Boland JA: The PrfA virulence regulon. Microbes Infect 2007, 9:1196-1207

24. SRINIVASAN, V.; NAM, H.M.; NGUYEN, L.T.; TAMILSELVAM, B.; MURINDA, S.E. and OLIVER, S.P. (2005): Prevalence of Antimicrobial Resistance Genes in Listeria monocytogenes Isolated from Dairy Farms. FOODBORNE PATHOGENS AND DISEASE; Volume 2, Number 3, 2005.

25. Theivagt, A.E., Friesen, J.A. (2006). "Purification and characterization of Listeria monocytogenes HMG-CoA reductase" FASEB Journal 20 (4, Part 1): A472 MAR 62006.

26. Todar, K. (2008):"Listeria monocytogenes". Todar's Online Textbook of Bacteriology. Retrieved January 28, 2009.

27. Travier, L., S. Guadagnini, E. Gouin, A. Dufour, V. Chenal- Francisque, P. Cossart, J. C. O livo- Marin, J. M. Ghigo, O. Disson and M. Lecuit (2013). "ActA promotes Listeria monocytogenes aggregation, intestinal colonization and carriage." PLoS Pathog9 (1): e1003131.

28. Vera A, Gonzalez G, Domınguez M, Bello H. 2013. Main virulence factors of Listeria monocytogenes and its regulation.RevChilenaInfectol. 30:407-416

29. Zeinali, T., Jamshidi, A., Bassami, M. and 4Rad, M. (2017)Isolation and identification of Listeria spp. in chicken carcasses marketed in northeast of Iran.International Food Research Journal 24(2): 881-887 (April 2017). 